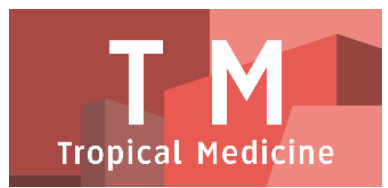

PAPER - OPEN ACCESS

\title{
Hubungan Tingkat Stres Dengan Strategi Koping Mahasiswa Reguler Profesi Ners Di Fakultas Keperawatan Universitas Sumatera Utara
}

\author{
Author $\quad$ : Indah Permata Sari Lombu \\ DOI $\quad: 10.32734 /$ tm.v1i1.55 \\ Paper Page : $36-40$
}

Volume 1 Issue 1 - 2018 TALENTA Conference Series: Tropical Medicine (TM)

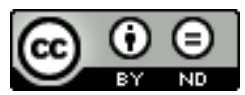

This work is licensed under a Creative Commons Attribution-NoDerivatives 4.0 International License.

Published under licence by TALENTA Publisher, Universitas Sumatera Utara
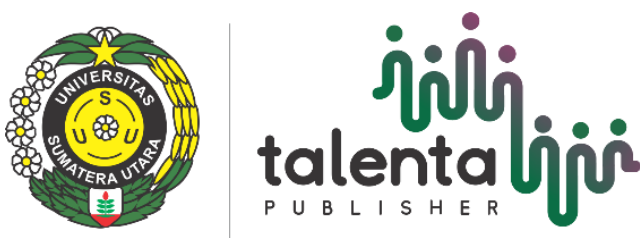


\title{
talentaำ \\ Available online at https://talentaconfseries.usu.ac.id
}

\section{Hubungan Tingkat Stres Dengan Strategi Koping Mahasiswa Reguler Profesi Ners Di Fakultas Keperawatan Universitas Sumatera Utara}

\author{
Indah Permata Sari Lombu ${ }^{\mathrm{a}, *}$, Setiawan $^{\mathrm{a}}$ \\ ${ }^{a}$ Fakultas Keperawatan, Universitas Sumatera Utara, Medan 20155, Indonesia \\ cerryn_sach27@yahoo.com, setiawan@usu.ac.id
}

\begin{abstract}
Abstrak
Pendidikan profesi ners adalah proses pendidikan yang sepenuhnya dilaksanakan di lahan praktik seperti rumah sakit, puskesmas, klinik bersalin, panti wherda, dan keluarga serta masyarakat atau komunitas. Mahasiswa yang menjalani pendidikan profesi ners rentan terhadap stres karena adanya transisi dari kehidupan kampus ke kehidupan lapangan, oleh karena itu mahasiswa menggunakan sejumlah strategi koping untuk mengatasi stres. Penelitian ini bertujuan untuk mengidentifikasi tingkat stres, strategi koping, dan hubungan tingkat stres dengan strategi koping mahasiswa reguler profesi ners di Fakultas Keperawatan Universitas Sumatera Utara. Desain penelitian ini adalah deskriptif korelasional. Penentuan jumlah sampel dilakukan dengan metode tabel power analisys. Besar sampel yang digunakan sebanyak 62 orang. Proses pemilihan sampel menggunakan teknik simple random sampling. Instrumen penelitian berupa kuesioner data demografi, kuesioner clinical stress, dan kuesioner coping strategy. Pengumpulan data berlangsung dari bulan Februari-April 2016. Data dianalisis menggunakan uji korelasi pearson. Hasil penelitian menunjukkan bahwa mahasiswa mengalami stres ringan $8.1 \%$, stres sedang $79.0 \%$, dan stres berat $12.9 \%$. Area klinik yang paling banyak menyebakan stres mahasiswa adalah interaksi dengan anggota tim kesehatan $(\mu=118.6)$. Mahasiswa yang kadang-kadang melakukan strategi koping $25.8 \%$, dan selalu melakukan strategi koping $74.2 \%$. Strategi koping yang paling banyak dilakukan mahasiswa adalah koping yang diantisipasi $(\mu=86)$. Berdasarkan hasil penelitian maka mahasiswa diharapkan mampu mempersiapkan diri dengan dengan baik sebelum dan selama menjalani praktek klinis dengan cara mempelajari pengetahuan asuhan keperawatan kepada klien melalui studi literatur, studi lapangan, diskusi dengan senior, diskusi dengan staf perawat, dan diskusi dengan pembimbing.
\end{abstract}

Kata Kunci: Mahasiswa Profesi ners; Tingkat Stres; Strategi Koping

\section{Pendahuluan}

Pendidikan profesi ners adalah proses dimana mahasiswa mengaplikasikan teori-teori dan konsepkonsesp yang telah didapat selama tahap akademik ke dalam masalah klinik yang nyata [6]. Mahasiswa yang menjalani program profesi rentan terhadap stres karena adanya transisi dari kehidupan kampus ke kehidupan lapangan [11].

Stres adalah ketidakmampuan untuk mengatasi ancaman (nyata atau bayangan) kesejahteraan mental, fisik, emosional, dan spiritual yang menghasilkan serangkaian respon fisiologis dan adaptasi [9]. Mulyadi pada [2] menemukan beberapa masalah yang menyebabkan stres pada mahasiswa profesi ners pada saat mengikuti praktek klinik di rumah sakit, antara lain: ketakutan dan panik dalam berkomunikasi dengan petugas kesehatan; bingung ketika harus melakukan tindakan asuhan keperawatan kepada klien; tidak mengerjakan tugas dalam melakukan praktek asuhan keperawatan kerena panik hingga mengalami ketegangan dalam bentuk gelisah; teguran atau didikan 
dari perawat rumah sakit (instruktur klinik) yang terkesan keras kepada mahasiswa; mahasiswa cemas dalam berkomunikasi karena kurang percaya diri, gugup dalam menyampaikan suatu gagasan atau ide.

Oleh karena itu mahasiswa menggunakan sejumlah strategi koping mengatasi stres untuk menjaga keseimbangan kesejahteraan dan mencegah penyakit [1]. Koping adalah proses dimana seseorang mencoba untuk mengatur perbedaan yang diterima antara keinginan (demands) dan pendapatan (resources) yang dinilai dalam suatu keadaan yang penuh tekanan [3]. Mahasiswa keperawatan menggunakan berbagai strategi koping untuk menghadapi stres seperti berpikir dan bersikap positif terhadap masa depan; mendengarkan musik; menonton TV; tidur; melamun; mencoba untuk memecahkan masalah; melakukan kegiatan olahraga dan pengalihan; membaca buku; berpikir negatif kepada sesama siswa, teman-teman dan orang lain; menggunakan strategi untuk mendapatkan penerimaan dari lingkungan staf selama praktik klinis; dan mencari dukungan dari orang lain [16].

Penelitian yang dilakukan oleh Suminarsis (2009) pada mahasiswa PSIK Universitas Muhammadiyah Surakarta yang sedang melaksanakan praktek klinik di RS dr. Moewardi menunjukkan bahwa tingkat stres responden rata-rata adalah sedang yaitu 22 responden (46\%), kategori berat sebanyak 13 responden (28\%), dan ringan sebanyak 12 responden (26\%). Rata-rata memiliki mekanisme koping adaptif yaitu sebanyak 27 responden (57\%), dan 20 responden (43\%) memiliki mekanisme koping maladaptif. Semakin berat tingkat stres mahasiswa, maka mahasiswa memiliki mekanisme koping maldaptif.

Mahasiswa keperawatan adalah komponen penting dari pelayanan kesehatan. Jika mahasiswa terampil dalam menangani stres maka mahasiswa akan mampu memberikan performa terbaik. Tanpa keterampilan dan kemampuan ini, penyediaan layanan perawatan berkualitas untuk pasien di bawah perawatan mahasiswa tidak dapat dijamin. Perencanaan dasar ini berkaitan dengan langkah-langkah intervensi yang akan dilakukan untuk membantu mahasiswa dalam menangani stres yang paling umum. Oleh karena itu, penelitian tentang hubungan tingkat stres dengan strategi koping mahasiswa reguler profesi ners di Fakultas Keperawatan Universitas Sumatera Utara sangat penting untuk dilakukan.

\section{Metode Penelitian}

Penelitian ini merupakan penelitian deskriptif korelasional. Populasi dalam penelitian ini adalah seluruh mahasiswa S1 reguler profesi ners Fakultas Keperawatan Universitas Sumatera Utara tahun 2015-1016. Penentuan jumlah sampel dilakukan dengan metode tabel power analysis yang memperkirakan jumlah sampel dengan derajat ketepatan $\alpha=0,05$ dengan analisa kekuatan (power) sebesar 0,8 dan effect size 0,35 sehingga didapatkan jumlah sampel sebanyak 62 orang [1]. Pengambilan sampel menggunakan tehnik probability sampling dengan pendekatan simple random sampling yang memberikan kesempatan yang sama kepada setiap anggota yang ada dalam populasi untuk dijadikan sampel.

Instrumen yang digunakan berupa kuesioner yang terdiri dari data demografi responden, clinical stress dan coping strategy. Kuesioner data demografi terdiri dari umur dan jenis kelamin. Kuesioner clinical stress terdiri dari 44 pernyataan. Kuesioner coping strategy terdiri dari 35 pernyataan. Instrumen clinical stress dan coping strategy diadopsi dari Singh dan Kohli [11]. Validitas isi kedua instrumen ditetapkan oleh 10 panel ahli di bidang psikologi klinik, keperawatan psikiatrik, dosen psikiatrik, dan administrator.

Uji reliabilitas dilakukan pada 30 responden yang sesuai dengan kriteria namun diluar dari sampel di Fakultas Keperawatan Universitas Sumatera Utara. Reliabilitas instrumen asli clinical stress adalah 0.99 dan coping strategy adalah 0.75. Reliabilitas instrumen terjemahan clinical stress adalah 0.95 dan coping strategy adalah 0.81. Jadi kedua instrumen telah reliabel dan dapat digunakan dalam penelitian. 


\section{Hasil Penelitian}

Hasil penelitian diuraikan dengan mendeskripsikan tingkat stres, strategi koping dan hubungan diantaranya. Kerusakan pada organ korti koklea hanya ditemukan pada kelompok yang diberi perlakuan bising $100110 \mathrm{~dB}$. Hal tersebut sejalan dengan penelitian Metidieri [5] bahwa pemaparan intensitas yang lebih dari $85 \mathrm{~dB}$ dengan 8 jam dapat menimbulkan kerusakan pada koklea bila dibandingkan dengan intensitas yang lebih rendah. Menurut penelitian Ewert [2], pada tikus yang diberi perlakuan bising dengan alat simulator berintensitas diatas $100 \mathrm{~dB}$ selama 21 hari dan dilakukan pemeriksaan histopatologi didapatkan gambaran terbentuknya jaringan parut pada daerah sel rambut yang rusak, stereosilia mengalami kerusakan, serta terpisahnya organ korti dari membran basilar.

Table. 1. Tingkat Stres Mahasiswa

\begin{tabular}{lcc}
\hline Tingkat Stress & Frekuensi & Persentase \\
\hline Stres Ringan & 5 & 8.1 \\
Stres Sedang & 49 & 79.0 \\
Stres Berat & 8 & 12.9 \\
\hline
\end{tabular}

Table. 2. Rata - Rata Area Stress Klinik Mahasiswa

\begin{tabular}{lc}
\hline Area Stres Klinik & Mean \\
\hline Kondisi Penyakit Pasien & 73 \\
Prosedur Keperawatan & 96 \\
Rotasi Klinik dan Pengkajian & 107.375 \\
Interaksi dengan Pasien/Keluarga & 89.5 \\
Interaksi dengan Anggota Tim Kesehatan & 118.6 \\
Interaksi dengan Fakultas & 110.57 \\
Interaksi dengan rekan Siswa / Senior & 77.2 \\
\hline
\end{tabular}

Table. 3. Strategi Koping Mahasiswa

\begin{tabular}{lcc}
\hline Strategi Koping & Frekuensi & Persentase \\
\hline Kadang-Kadang & 16 & 25.8 \\
Selalu & 46 & 74.2
\end{tabular}

Table. 4. Rata-rata Strategi Koping Mahasiswa

\begin{tabular}{lc}
\hline Strategi Koping & Mean \\
\hline Strategi Kpoping & 55.28 \\
Venting/Pelepasan & 73.6 \\
Melarikan Diri & 64 \\
Menerima Tanggung Jawab & 80.25 \\
Mencari Dukungan Sosial & 80.75 \\
Pemecahan Masalah & 81.25 \\
Koping yang diantisipasi & 86 \\
Berkhayal & 76 \\
\hline
\end{tabular}


Table. 5. Hubungan tingkat stres dengan strategi koping Mahasiswa

\begin{tabular}{lcc}
\hline Variabel Tingakat Stres Mahasiswa & $\begin{array}{c}\text { Pearson Correlation } \\
(\mathbf{r})\end{array}$ & P value \\
\hline Strategi Koping Mahasiswa & 0.293 & 0.021 \\
\hline
\end{tabular}

\section{Pembahasan}

Hasil penelitian menunjukkan bahwa sebanyak 79.0\% mahasiswa reguler profesi ners di Fakultas Keperawatan USU memiliki tingkat stres sedang. Hal ini sejalan dengan penelitian [11][7][8] yang menunjukkan bahwa mahasiswa tersebut juga lebih banyak mengalami tingkat stres sedang.

Area klinik dapat menyebabkan stres pada mahasiswa [13]. Interaksi dengan anggota tim kesehatan merupakan area klinik yang paling banyak menyebabkan stres pada mahasiswa. Stres terkait interaksi dengan anggota tim kesehatan yaitu sikap tidak peduli terhadap mahasiswa perawat oleh staf bangsal, staf perawat mendelegasikan tanggung jawab perawatan pasien kepada mahasiswa, tidak mampu menguasai instruksi dari instruktur klinis dan staf bangsal pada waktu yang sama, perilaku yang tidak menyenangkan dari anggota tim kesehatan, staf perawat yang sangat kasar. Berbeda dengan Shaban pada [10] yang mengatakan bahwa area klinik yang paling banyak menyebabkan stres pada mahasiswa keperawatan adalah pengkajian dan beban kerja.

Keberhasilan pembelajaran klinik dipengaruhi oleh kesiapan pengetahuan, mental, emosi dan ketersediaan lingkungan pembelajaran yang kondusif [13]. Nurhidayah pada [5] juga mengatakan pelaksanaan pembelajaran klinik terkait erat dengan peran pengajar (perseptor) [5] membagi tujuh metode pembelajaran klinik, yaitu: (1) experiential: meliputi penugasan klinis, tugas tertulis, simulasi dan permainan, (2) pemecahan masalah: meliputi situasi pemecahan masalah, dan situasi pembuatan keputusan, (3) konferensi: biasanya terdiri dari konferensi prapertemuan, pascapertemuan, dan jenis pertemuan klinis lainnya serta pertemuan keperawatan multi disiplin, (4) observasi: meliputi observasi di lingkungan klinik, kunjungan lapangan atau home visit, ronde keperawatan, dan peragaan, (5) multimedia: biasanya terkait dengan keragaman media yang digunakan dalam penyampaian materi misalnya bentuk visual seperti slide dan film strip, bentuk auditori seperti videotip dan dengan menggunakan model atau objek lain untuk dimanipulasi, model cetakan seperti: hand out, pamplet, buku ajar, buku kerja/buku panduan serta instruksi terprogram, jenis media bukan cetakan seperti kaset/audiotif, komputer, film, film loop, film streep, model, overhead trasparansi, fotografi, objek nyata, slide, televisi, videotip, (6) self directed yaitu: seperti kontrak pembelajaran, pembelajaran sendiri, dan (7) preceptorship dan model lain dari praktek klinik terkonsentrasi. Preceptorship didasarkan pada konsep modeling peserta didik dengan cara memodifikasi prilaku dan mengobservasi sendiri prilaku yang dibutuhkan.

Hasil penelitian juga menunjukkan bahwa sebanyak 74.2\% mahasiswa selalu melakukan strategi koping. Hal ini sejalan dengan penelitian Singh dan Kohli [11] yang menunjukkan bahwa mahasiswa keperawatan selalu melakukan strategi koping. Koping yang diantisipasi merupakan strategi koping yang paling sering dilakukan oleh mahasiswa reguler profesi ners Fakultas Keperawatan USU. Strategi koping terkait koping yang diantisipasi yaitu mengantisipasi kesulitan dan mempersiapkan diri secara emosional, bicara kepada seseorang untuk mengetahui lebih lanjut tentang situasi, bertanya kepada seseorang yang dihormati untuk meminta saran dan mengikutinya. Namun Nelwati [4] menyatakan bahwa pemecahan masalah merupakan strategi koping yang sering digunakan oleh mahasiswa yang sedang menjalani program pendidikan profesi.

Analisis hubungan tingkat stres dengan strategi koping mahasiswa menunjukkan nilai $r$ positif, artinya semakin berat tingkat stres mahasiswa maka mahasiswa semakin selalu melakukan strategi koping. Hubungan tingkat stres dengan strategi koping mahasiswa adalah rendah ( $\mathrm{r}=0.293$ ). Hasil uji statistik lebih lanjut menunjukkan bahwa adanya hubungan yang bermakna dan signifikan antara tingkat stres dengan strategi koping mahasiswa $(\mathrm{p}=0.021)$. Dari hasil analisis korelasi Pearson, maka dapat diketahui bahwa hipotesis penelitian terbukti yakni adanya hubungan tingkat stres dengan strategi koping mahasiswa reguler profesi ners di Fakultas Keperawatan Universitas Sumatera Utara. 
Hal ini sejalan dengan penelitian Suminarsis [12] terhadap 47 orang mahasiwa program studi S1 Keperawatan Universitas Muhammadiyah Surakarta yang telah melaksanakan praktik belajar lapangan di rumah sakit yang mengatakan bahwa ada hubungan antara tingkat stres dengan strategi koping mahasiswa dengan nilai $\mathrm{p}=0.001$. Demikian juga dengan penelitian [14] terhadap 76 orang mahasiswa ners Universitas Respati Yogyakarta yang mengatakan bahwa ada hubungan antara tingkat stres dengan strategi koping mahasiswa dengan nilai $\mathrm{p}=0.028$.

Secara teori, koping berkaitan erat dengan stres. Seperti yang dikatakan Lazarus dan Folkman [16] koping didefinisikan sebagai strategi perilaku dan kognitif yang digunakan oleh individu untuk mengatasi situasi yang penuh stres. Yesil, Oztunc, dan Esklmez [15] juga menambahkan bahwa koping stres didefinisikan sebagai respon kognitif, perilaku atau emosional yang diberikan dengan untuk menanggung, mengurangi atau menghilangkan ketegangan yang disebabkan oleh peristiwa atau situasi stress.

\section{Kesimpulan}

Tingkat stres mahasiswa adalah tingkat stres sedang. Area klinik yang paling dominan menyebabkan stres pada mahasiswa adalah interaksi dengan anggota tim kesehatan. Mahasiswa selalu melakukan strategi koping untuk menghadapi situasi stres. Strategi koping yang paling sering dilakukan adalah koping yang diantisipasi. Dari hasil analisis korelasi Pearson, diketahui bahwa hipotesis penelitian terbukti yakni adanya hubungan tingkat stres dengan strategi koping mahasiswa reguler profesi ners di Fakultas Keperawatan Universitas Sumatera Utara. Semakin tinggi tingkat stres mahasiswa maka mahasiswa semakin selalu melakukan strategi koping. Hubungan tingkat stres dan strategi koping mahasiswa adalah rendah namun bermakna dan signifikan.

\section{Referensi}

[1] Demir, S., Demir, S. G., Bulut, H., \& Hisar, F. (2014) "Effect of mentoring program on ways of coping with stress and locus of control for nursing students". Asian Nursing Research, 8:254-260.

[2] Mulyadi, E. (2014) "Hubungan mekanisme koping individu dengan kecemasan komunikasi interpersonal pada mahasiswa profesi ners". Jurnal. Diterima dari http://www.download.portalgaruda.org

[3] Nasir, A., \& Muhith, A. (2011) "Dasar-dasar keperawatan jiwa: Pengantar dan teori”. Jakarta: Salemba Medika

[4] Nelwati. (2009). "Hubungan antara sumber stres dengan koping mahasiswa keperawatan program pendidikan profesi ners". Ners Jurnal Keperawatan Universitas Andalas. Diterima dari http://fkep.unand.ac.id

[5] Nurhidayah, R. E. (2011) "Pendidikan keperawatan pendekatan kurikulum berbasis kompetensi”. Medan: USU Press

[6] Nurhidayati, T. (2011) “Tingkat stres mahasiswa profesi ners stase komunitas Universitas Muhammadiyah Semarang”. Jurnal Keperawatan, 7(1):1-7

[7] Rezkia, P. (2009) "Hubungan tingkat stressor dengan strategi koping mahasiswa keperawatan universitas riau dalam mengatasi stres melaksanakan tahap profesi”. Jurnal. Diterima dari http://www.repository.unri.ac.id/

[8] Salsabila, I. (2015) "Pengalaman stres praktik klinik dan tingkat stres pada mahasiswa keperawatan tahun pertama dan tahun kedua praktik klinik Universitas Islam Negeri Syarif Hidayatullah Jakarta”. e-Skripsi. Diterima dari http://repository.uinjkt.ac.id/dspace/bitstream/123456789/30588/1/INAYATI\%20SALSABILAFKIK.pdf

[9] Seaward, B. L. (2014). Essentials of managing stress (3rd ed.). Canada: Jones \& Bartlett Learning

[10] Shaban, I. A., Khater, W. A., \& Akhuzaheya, L. M.. (2012). Undergraduate nursing studentse stress sources and coping behaviors during their initial period of clinical training: A Jordanian perspective. Nurse Education in Practic, 204-209. doi:10.1016/j.nepr.2012.01.005

[11] Singh, N., \& Kohli, C. (2015). Stress reaction and coping strategies among nursing students in Delhi. Asian J. Nursing Education and Research, 5(2), 274-278. doi:10.5958/2349-2996.2015.00054.3

[12] Suminarsis, T. A. (2009). Hubungan antara tingkat stres dengan mekanisme koping pada mahasiswa keperawatan menghadapi praktek belajar lapangan di rumah sakit. Jurnal. Diterima dari http://eprints.ums.ac.id/6434/1/ J1210050085.pdf

[13] Syahreni, E., \& Waluyanti, F. T. (2005). Pengalaman mahasiswa s1 keperawatan program reguler dalam pembelajaran klinik. Jurnal Keperawatan Indonesia, 11(2), 47-53

[14] Wiyani, C. (2013). Hubungan tingkat stres dengan mekanisme koping dan sikap dalam menjalankan profesi ners pada mahasiswa Universitas Respati Yogyakarta angkatan 2013. Jurnal. Diterima dari journal.respati.ac.id

[15] Yesil, P., Oztunc, G., \& Esklmez, Z. (2015). Personal characteristics and styles of coping with stress of nursing students of a university in turkey. Journal of Nursing Education and Practice, 5(5), 7381. doi:10.5430/jnep.v5n5p73

[16] Yobas, P. K., Keawkerd, O., Pumpuang, W., Thunyade, C., Thanoi, W., \& He, H. G. (2013). The mediating effects of coping on the stress and health relationships among nursing students: A structural equation modelling approach. JAN Informing Practice and Policy Worldwie through Research and Scholarship, 1287-1298 